\title{
Beşinci Sınıf Öğrencilerinin Veri İşleme Konusundaki Kazanımlara Ulaşabilme Durumlarının Belirlenmesi
}

\author{
Determining the Data Processing Learning Domain \\ Attainments of $5^{\text {th }}$ Grade Students
}

\section{Mihriban HACISALİHOĞLU KARADENIZ*}

Öz: Bu araştırma, beşinci sınıf öğrencilerinin veri işleme konusundaki algılayışlarını ortaya çıkarmayı amaçlayan nicel metodolojinin kullanıldığı bir durum saptama çalışmasıdır. Araştırmanın çalışma grubunu 2014-2015 eğitim-öğretim yılında Giresun ilinde bulunan iki ortaokulun beşinci sınıfinda öğrenim gören toplam 53 öğrenci oluşturmaktadır. Veri toplama aracı olarak, veri işleme konusuna yönelik altı soru kullanılmıştır. Sorular, veri işleme konusunu hedef alan kazanımlara odaklanarak hazırlanmıştır. Elde edilen verilerin analizi sonucunda öğrencilerin, araştırma sorusu üretme, veri toplama, düzenleme ve gösterme, veri analizi ve yorumlamada, verilerin farklı temsil biçimlerinden grafik, tablo ve şema oluşturma ve bunları yorumlama konusunda güçlük yaşadıkları sonucunu ortaya koymaktadır. Çalışmadan elde edilen bulgular ışı̆̆ında, öğrencilere veri konusunda deneyim kazandırırken; tablo, grafik ve şema biçimindeki temsillerine yönelik yakın çevrelerinden çeşitli örnekler sunulmalı, materyalle desteklenerek dikkatleri çekilmeli, çeşitli yöntem ve tekniklerden yararlanarak konuyu daha iyi kavramaları sağlamalıdır. Bununla birlikte sınıf içi uygulamalarda; araştırma sorusu üretme, veri toplama, veri düzenleme ve gösterme, veri analizi ve yorumlamayı içeren etkinliklere daha fazla yer verilmesi önerilebilir.

Anahtar sözcükler: Ortaokul Matematik Dersi Öğretim Programı, Veri İşleme Öğrenme Alanı, Ortaokul Beşinci Sınıf Öğrencileri

\begin{abstract}
This study, is a situation determination study employing quantitative methodology for the purpose of revealing the data processing perceptions of 5th grade students. The study group consisted of $535^{\text {th }}$ grade students from two secondary schools in Giresun in the 2014-2015 academic year. As the data collecting tool, six questions on the topic of data processing were employed. Questions were prepared by focusing on the achievements which forms the subject of data processing. As a result of the analysis of the obtained data, students can create a research question that requires the students to collect data. However, the research question showed the students had no ideas concerning the reasons for creating the data. Yet an another result shows that almost every student has difficulties with creating data frequency table and column chart, arranging the schema; interpreting and summarizing the data which is shown with the frequency table, column chart and tree diagram. While providing data processing experience to the students, in the light of the results obtained from the study; students must be presented with several examples from their near environment concerning the data subject's table, graph and their representation in the schema format, the subject must be supported with the materials to draw the student's attention, such as plays or dramas, with the help of several techniques and methods. The subject must be ensured to better process the data. In addition to this, during in-class applications; giving more space to research question generation, data collection, data editing and display, data analysis and interpretation activities can be recommended.
\end{abstract}

Keywords: The Education Program of Elementary School Mathematics Studies, Data Processing Learning Domain, $5^{\text {th }}$ Grade Students.

\footnotetext{
*Yrd. Doç. Dr., Giresun Ün. Eğitim Fak., İlköğretim Böl., Matematik Eğitimi ABD, Giresun, mihrideniz61@gmail.com Bu çalışma 16-18 Mayıs 2015 tarihlerinde Adıyaman'da düzenlenen II. Türk Bilgisayar ve Matematik Eğitimi Sempozyumu'nda sunulan bildirinin genişletilmiş halidir.
} 
NCTM, 2000 yılında yayınladığı dokümanda; okul öncesi dönemden 12. sınıfın sonuna kadar farklı düzeylerde matematiğin genel ilkelerinin neler olması ve matematiksel içerik ve süreçlerin hangi standartları sağlaması gerektiğini belirtmiştir. $\mathrm{Bu}$ dokümana göre içerik standartları; sayılar-işlemler, cebir, geometri, ölçme, veri analizi-olasılık olmak üzere beş ana başlık altında toplanmıştır. Ayrıca veri toplama sürecini planlama, deney, anket ya da gözlemle veri toplama ve verileri tablo, çizgi grafiği, sütun grafiği ve şema kullanarak gösterebilme becerisi de vurgulanmaktadır (NCTM 2000). Bununla birlikte Türk Milli Eğitim Bakanlığı da 2013 yılında güncellenen Ortaokul Matematik Dersi Öğretim Programında öğrenme alanlarını benzer bir şekilde ele almıştır (MEB 2013). Bu bağlamda veri işleme konusu, tüm sınıf seviyelerinde yer almakta, beşinci sınıf seviyesinde bu konuya ilişkin öğrencilerden veri toplamayı gerektiren araştırma soruları oluşturmaları, bu sorulara uygun veriyi çetele tablosu, sıklık tablosu, ağaç şeması ve sütun grafiğinde göstermeleri ve yorumlamaları beklenmektedir (MEB 2009a; 2009b; 2013).

İlköğretimde veri konusu işlenirken farklı gösterimlerde kullanılan sayı, sembol ve noktaların ne anlama geldiği tartışılmalı, bu sayının bazen verinin sayısal değerini gösterirken bazen de o verinin sıklığını gösterebildiği öğrenciye sezdirilmelidir. Örneğin, bir sayı bazen bir öğrencinin boyunu gösterirken bazen de "Beş kişi futbol oynamaktan hoşlantyor" gibi bir verinin kaç kez tekrar ettiğini gösterebilir. $\mathrm{Bu}$ durum, öğrenciye veriyi farklı yollarla göstermeyi, bunu anladıkça da farklı gösterimleri karşılaştırabilmeyi kazandırabilir (MEB 2009). Öğrencilerin verilerin yer aldığı içerik doğrultusunda tablo, grafik gibi farklı temsil biçimlerini kullanarak verileri oluşturma, okuma ve yorumlama becerilerini geliştirmelerinde bu temsil biçimlerinin önemi vurgulanmaktadır (Temiz \& Tan 2009). Dolayısıyla verilerin bu tür grafik ve tablo olarak düzenlenmesi onların daha iyi anlaşılmasına ve yorumlanmasına yardımcı olacaktır (Çepni, Ayas, Johnson \& Turgut 1997).

Verilerin yer aldığı içeriklerden; tablo, grafik ve şekil gibi temsil biçimlerinden grafik gösterimine bakıldığında matematik bilimi dışında (Özgün-Koca 2001) fen ve sosyal bilimlerde de bu gösterimden yararlanılmaktadır. Gösterimler, kavramsal anlamanın yanında problem çözme becerilerinin gelişimi açısından da önemlidir (Schultz \& Waters 2000). Örneğin; bir finans danışmanı, döviz kurlarını tahmin etmek için grafik gösteriminden yaralanarak grafik çizebilir, çizdiği grafikle ilgili tahmin yapabilir, böylece problemine bir çözüm üretmiş olur. Ayrıca bilinçli bir tüketici, gözlem becerisini kullanarak veri toplayabilir, verileri yorumlayarak bilimsel bir sonuç çıkarabilir (Tan \& Temiz 2003). Bu bağlamda tablolar ve grafikler, günlük yaşamda özellikle medyada niceliklerin ifade edilmesinde ve bunlara bağlı geliştirilen düşüncelerin desteklenme ve iletişiminde kullanılmaktadır. Dolayısıyla yaşamımızla ilgili birçok konuda doğru bilgi edinmede verileri, grafik ya da tablo olarak düzenleyerek onlardan yararlanabilme becerisi kazanmak önem taşımaktadır (Taşar, Temiz \& Tan 2002).

Hughes ve Wade'e (1993) göre, öğrencilerin araştırma yaparken olaylar ve nesneler hakkında verileri toplaması, bu verileri herkesin anlayabileceği şekilde düzenleyerek ve formlara kaydetmesi önemli görülmekte bunun yanı sıra bu formlar verilerin kullanılmasında ve okuyucuya ulaşmasında kolaylıklar sağlamaktadır. Böylece bir araştırma sonunda toplanan verileri yorumlayabilmenin en iyi yolu onları, grafik, tablo, çizelge ve histogram gibi gösterimlere dönüştürebilmektir (Bailer, Ramig \& Ramsey 1995; Martin 2002). Görüldüğü üzere tablolar, çizelgeler, grafikler ve şemalar verileri organize ederek yorumlama yapabilmeyi ve sonuca ulaşabilmeyi sağlar. Dolayısıyla bu durum, öğrencilerin süreçte veri konusunda; çetele ve sıklık tablosu, nesne, şekil, sütün, çizgi ve daire grafiği ve ağaç şeması gösterim biçimleri ile ilgili yeterli düzeyde bilgi ve beceri sahibi olmasını gerektirmektedir. Yapılan çalışmalar, öğrencile- 
rin çeşitli sınıf düzeyinde ve matematik dışındaki, fen ve sosyal bilimler gibi disiplinlerde, grafik ve diğer gösterim biçimlerinde önemli ölçüde güçlükler yaşadıklarını göstermektedir. Bu güçlükler; tablo oluşturma, çeşitli grafikleri düzenleme, bunları okuma ve yorumlama, grafik ile diğer gösterim biçimlerini ilişkilendirme olarak karşımıza çıkmaktadır (Bell \& Janvier 1981; Padilla, McKenzie \& Shaw 1986; Clement 1989; Leinhardt, Zaslavsky \& Stein 1990; Brasell \& Rowe 1993; Berg \& Philips 1994; Çelik \& Sağlam-Arslan 2012).

İlköğretim Matematik Dersi 1-5. Sinıflar ve 6-8. Sinıflar Öğretim Programında (MEB 2009a; 2009b), öğrencilerin veri toplaması, veriyi tablo ya da grafik biçiminde özetleme yoluyla cevaplayabileceği problemler oluşturabilmesi amaçlanmaktadır. Öğretim programında somut model, şekil, resim, grafik, tablo gibi temsil biçimlerini kullanarak matematiksel düşüncelerini ifade etme, günlük dili, matematiksel dil ve sembollerle ilişkilendirme, öğrenme alanları arasında ilişki kurma ve matematiği diğer derslerde ve günlük yaşamda kullanma ifadeleri ile temsiller arası geçişlerin önemine vurgu yapılmaktadır. Bu bağlamda ekonomi, politika, bilimsel araştırma ve bunları günlük hayatla ilişkilendirmede çok büyük kolaylıklar sağlayacak pek çok veri çeşidinden söz edilebilir. Öğrenciler bilinçli vatandaş olabilmek için veri toplamayı ve bunları analiz edebilmeyi bilmeli ve istatistikle ilgili akıl yürütme becerisine sahip olabilmelidirler. Bunun için basit sınıflama, sıralama, eşleştirme, karşılaştırma ve sayma etkinlikleri; veri işleme ve analiz etmede istatistik konusu için hazırbulunuşluk oluşturabilir. Öğrenciler, öncelikle kendileri için anlamlı olacak sorular oluşturmaya ve bu sorulara verilen cevapları belirlemeye, verilen cevapları düzenlemeye yönlendirilmeli, sonra topladıkları veriyi, gerek tablo gererekse grafik olarak düzenleyebilmelidir. Öğrenciler bu süreçte çetele ve sıklık tablosu ile grafikleri kullanabilmeli, oluşturulan gösterimlerde, başlıklar açıkça belirtilmeli, veriler; tablo ya da grafik halinde düzenlendikten sonra veri analizine yönlendirilmelidirler. İlköğretimin ilk yıllarında öğrenciler veriyi bir bütün olarak görmekte zorlanabilir ancak "daha az", "daha çok", "eşit" ve "farklı" gibi basit karşılaştırmaları yapabilirler. Beşinci sınıfın sonuna doğru, öğrenciler veriyi bir bütün olarak görmeye ve yorumlamaya başlarlar (MEB 2009).

Matematik eğitimi, öğrencilerin matematiksel düşüncelerini ifade ederken veri ile ilgili yeterli bilgi ve beceriyi kazandırma konusunda özel bir amacının olduğu görülmektedir (MEB, 2009a, 2009b, 2013). “İlköğretim Matematik Dersi 1-5. Sınıflar Öğretim Programı” ve "İlköğretim Matematik Dersi 6-8. Sınıflar Öğretim Programı” 2013 yılında güncellenerek "Ortaokul Matematik Dersi (5, 6, 7 ve 8. Sınıflar) Öğretim Programı” adını almıştır. Programda beşinci sınıf seviyesinde "Veri İşleme" öğrenme alanına ilişkin öğrencilerden; veri toplamayı gerektiren araştırma soruları oluşturmaları, bu sorulara uygun veriyi tablo, sıklık tablosu, ağaç şeması ve sütun grafiğinden uygun olanları ile göstermeleri ve yorumlamaları beklenmektedir. Altınc1 sınıf seviyesinde ise iki veri grubuna ilişkin veri elde etmeleri, bu verileri düzenlemeleri ve analiz etmeleri beklenmektedir. Öğrencilerin iki gruba ait verileri karşılaştırmada ve yorumlamada aritmetik ortalama ve açıklık kullanması bu seviyede hedeflenen kazanımlar arasındadır. Yedinci sınıfta daire ve çizgi grafiği kavramları ele alınmakta ve öğrencilerin bu grafikleri yorumlamaları beklenmektedir. Bunların yanı sıra ortalama, ortanca ve tepe değer kavramlarının öğrenciler tarafından anlaşılması, hesaplanması ve yorumlanması beklenmekte ve verileri uygun olan gösterimler ile sunmaları istenmektedir. Sekizinci sınıfa gelindiğinde ise histogram ile verilerin gösterimi ve yorumlanması programda yer almaktadır (MEB 2013).

Görüldüğü üzere, Türkiye'de 2013 y1lında güncellenerek uygulamaya konulan öğretim programı incelendiğinde, veri konusuna her sınıf düzeyinde yer verildiği anlaşılmaktadır. Çalışmada güncellenen programın beşinci sınıfinda, "Veri İşleme" öğrenme alanı; "Araştırma Soruları Üretme, Veri Toplama, Düzenleme ve Gösterme”, "Veri Analizi ve Yorumlama” alt 
öğrenme alanlarını oluşturmakta ve bu alanları doğrudan içeren dört kazanım bulunmaktadır. Bu kazanımlar; "Veri toplamayı gerektiren araştırma soruları oluşturur", "Araştırma sorularına ilişkin verileri toplar veya ilgili verileri seçer; veriyi uygunluğuna göre slkllk tablosu ve sütun grafiğiyle gösterir.", "Slklık tablosu, sütun ve ă̆aç şemasını ile gösterilmiş veriyi özetler ve yorumlar." ve "Ağaç şemasl yaparak verileri düzenler" şeklinde ele alınmaktadır (MEB 2013). Türkiye'de veri işleme konusundaki kazanımlara yönelik ortaokul öğrencileri ile yürütülmüş az sayıda çalışmanın var oluşu, bu araştırmanın yapılmasını gerekli kılmıştır. Buradan hareketle, bu araştırma beşinci sınıf öğrencilerinin veri işleme konusundaki algılayışlarını ortaya çıkarmayı amaçlamaktadır. Bir başka deyişle, beşinci sınıf öğrencilerinin araştırma sorusu üretme, veri toplama, düzenleme ve gösterme, veri analizi ve yorumlamada, verilerin farklı temsil biçimlerinden grafik, tablo ve şema oluşturma ve bunları yorumlama konusuna ilişkin algılayışlarının ortaya çıkartılması amaçlanmaktadır

\section{Yöntem}

$\mathrm{Bu}$ araştırma, nicel metodolojinin kullanıldı̆̆ katılanlar ve çalışmanın konusu göz önüne alındığında, bu araştırma özel durum çalışması niteliğindedir. Çünkü özel durum çalışmaları araştırılan konunun derinlemesine incelenmesine imkân sağlamakta, verilerin birbirleriyle olan ilişkilerini inceleyip sebep-sonuç ilişkilerini açıklayabilme firsatı vermektedir (Çepni 2014).

\section{Çalışma grubu}

Çalışma grubunu 2014-2015 eğitim-öğretim y1lında Giresun ilinde bulunan iki ortaokulun beşinci sınıfinda öğrenim gören toplam 53 beşinci sınıf öğrencisi oluşturmaktadır. Araştırmaya katılan öğrencilerin isimleri çalışma etiği gereği gizli tutulmuş ve öğrenciler; "Ö1, Ö2, Ö3,........, Ö53" olarak kodlanmıştır.

\section{Veri Toplama Aracı ve Verilerin Analizi}

Çalışmada veri toplama aracı olarak geliştirilen ve kullanılan sorular, alınyazında "Veri İşleme" öğrenme alanının alt öğrenme alanlarında yer alan kazanımlara yönelik yapılan çalışmalar ve uzman görüşleri dikkate alınarak hazırlanmıştır. Çalışmanın problemi, öğrencilerin temel düzeydeki veri konusuna ilişkin algılayışlarını belirlemek olduğundan, beşinci sınıf öğrencilerinin veri işleme konusundaki kazanımları algılayışlarını ortaya çıkarmak amaçlanmıştır. Sorular hazırlanırken beşinci sınıf öğretim programında yer alan "Veri İşleme” öğrenme alanının; "Araştırma Soruları Üretme, Veri Toplama, Düzenleme ve Gösterme” ve "Veri Analizi ve Yorumlama” alt öğrenme alanlarında yer alan kazanımlara odaklanılmıştır (MEB, 2013). Bu kazanımlar programda;

K1. "Veri toplamayı gerektiren araştırma soruları oluşturur"

K2. "Araştırma sorularına ilişkin verileri toplar veya ilgili verileri seçer; veriyi uygunluğuna

göre sıklık tablosu ve sütun grafiğiyle gösterir."

K3. "Sıklık tablosu, sütun ve ağaç şemasını ile gösterilmiş veriyi özetler ve yorumlar."

K4. "Ağaç şeması yaparak verileri düzenler"

olarak ele alınmaktadır (MEB 2013). Hazırlanan soruların kapsam geçerliliği ve okunabilirliği ilgili alanlarda uzmanlar tarafından incelenmiş, bunlardan okunabilirliği düşük olan 4 soru çıkarılmıştır. Yürütülen bu çalışmada veri toplama aracı olarak, birinci ve üçüncü soru iki şıklı, 
altıncı soru üç şıklı olmak üzere toplam on soru kullanılmıştır. Çalışmada yer alan soruların odaklandığı kazanımlar; 'K1', 'K2', 'K3', 'K4' ve kazanımlara ilişkin sorular ise; 'S1a' 'S1b' 'S2' 'S3a' 'S3b' 'S4' 'S5' 'S6a' 'S6b' ve 'S6c' şeklinde kodlanarak Tablo 1'de sunulmuştur.

Soruların geçerlik ve okunabilirliğinin belirlenmesi amacıyla uzman görüşüne başvurulmuş ve soruların araştırmanın amacı dikkate alınarak incelenmesi sağlanmıştır. Uzman görüşleri doğrultusunda tekrar düzenlenen sorular öğrencilere, araştırmacının katılımıyla uygulanmış ve cevaplamaları için 40 dakika zaman verilmiştir. Öğrencilerin sorulara verdikleri cevaplar, doğruluk bakımından kategorilere ayrılarak, kategorilerde ye alan öğrenci sayıları tablolar halinde bulgular kısmında sunulmuştur. Bununla birlikte beş öğrencinin katıldığ 1 bir pilot uygulama yapılmış, bu doğrultuda sorular, sınıf ortamında 40 dakikalık süre sınırlamasıyla uygulanmıştır. Pilot uygulamada ayrıca soruların uygulandığı öğrencilerle 20 dakikalık bir görüşme yapılmış, ardından soruların son şekli verilmiştir.

Verilerin analizi yapılırken öğrencilerinin sorulara verdikleri cevaplar; doğru (geçerliliği olan cevabın bütün yönlerini içeren cevaplar), yanlış (bilimsel olarak yanlış olan cevaplar), boş (boş bırakma, anlamsız cevaplar verme, bilmiyorum veya anlamadım şeklindeki cevaplar) biçiminde kategorilere ayrılarak frekans (f) ve yüzdeler (\%) hesaplanmıştır. Bunun yanı sıra sorulara katılımcıların verdikleri cevaplardan ve şekil üzerindeki gösterimlerinden alıntılar yapılarak ortaya çıkan durumlar örneklendirilmiştir.

Çalışmanın alt problemlerinin ışı̆̆ında soruların odaklandığı kazanımlar ve onlara ilişkin sorular Tablo 1'de sunulmuştur.

Tablo 1. Çalışmada Yer Alan Sorular ve Soruların Odaklandığı Kazanımlar.

Odak Noktaları
(Kazanımlar)

$\begin{array}{ll} & \text { S1. Aşağıdaki sorulardan hangisi istatiksel araştırma sorusudur? Neden? } \\ & \text { a) Okulumuz 3. sinıf öğrencileri } 23 \text { Nisan Ulusal Egemenlik ve Çocuk } \\ \text { K.1. Veri toplamayı } & \text { Bayramı'nda hangi etkinliklerin yer almasını istemektedir? } \\ \text { gerektiren araştırma } & \text { b) Beşinci sınıf öğrencisi Yusuf'un en çok sevdiği müzik türü hangisidir? } \\ \text { soruları oluşturur. } & \text { S2. Bir hava yolu firmasına sahip olduğunuzu düşününüz. Sizin firmanızla } \\ & \text { seyahat etmeyi tercih eden yolcuların sayısı arttırmak istiyorsunuz. } \\ & \text { Bu amaçla müşterileriniz sizin hizmetinizle ilgili memnuniyet ve şikâyetlerini } \\ & \text { öğrenmeniz için yapacağınız araştırmada onlara ne tür sorular sorarak, } \\ & \text { yolcuların görüşleri hakkında bilgi sahibi olursunuz. }\end{array}$

S3. Türkiye'nin katıldığı bazı olimpiyat oyunlarında kazandığı madalya sayıları aşağıdaki çetele tablosunda verilmiştir.

\section{K.2. Araştırma sorularına ilişkin verileri toplar veya ilgili verileri seçer; veriyi uygunluğuna göre sıkl1k tablosu ve sütun grafiğiyle gösterir.}

\begin{tabular}{|l|l|l|l|}
\hline $\begin{array}{l}\text { Olimpiyat } \\
\text { Oyunları }\end{array}$ & $\begin{array}{l}\text { Altın } \\
\text { Madalya }\end{array}$ & $\begin{array}{l}\text { Gümüşs } \\
\text { Madalya }\end{array}$ & $\begin{array}{l}\text { Bronz } \\
\text { Madalya }\end{array}$ \\
\hline Sydney 2000 & I/I & & // \\
\hline Atina 2004 & I/I & IIII & III \\
\hline Pekin 2008 & $/$ & III & III \\
\hline Londra 2012 & $/ /$ & /I & $/$ \\
\hline
\end{tabular}

Not: Her çizgi 2 madalyayı göstermektedir. S3a. Siklık tablosunu çiziniz.

S4. Aynı mobil iletişim şirketi ve aynı tarifeye üye olan Hasan,

Ahmet, Hülya, Murat, Yasemin'in cep telefonu faturası dökümlerine göre bir ayda gönderdikleri kısa mesaj sayıları sırasıyla 110, 100, 85, 55, 145'tir. Bu verilere ilişkin sütun grafiğini oluşturunuz. 
S3b. Türkiye belirtilen dört olimpiyat oyununda en fazla madalyayı hangi olimpiyat oyununda kazanmıştır?

S6. Meteoroloji Genel Müdürlüğü tarafindan hazırlanan ve 2012 yılında bölgelerimize düşen yağış miktarını gösteren grafik aşağıda verilmiş̧tir.

K.3. Siklık tablosu, sütun ve ağaç şemasını ile gösterilmiş veriyi özetler ve yorumlar.

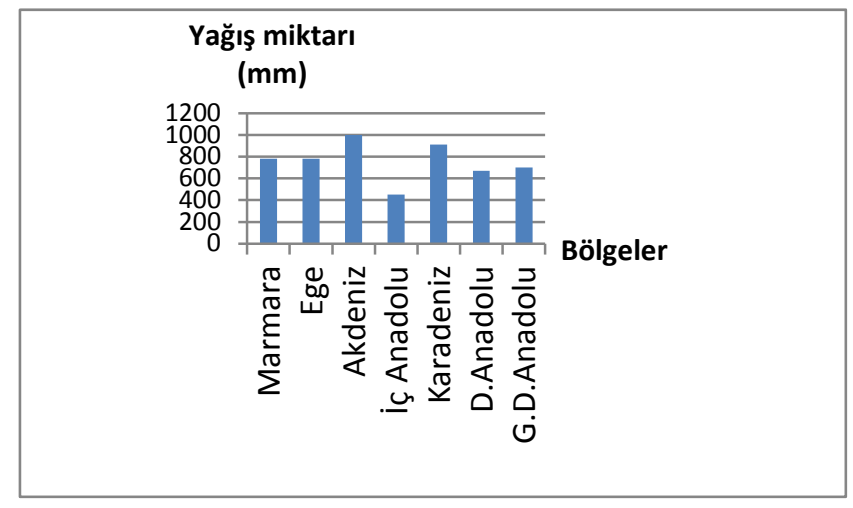

S6a. Karadeniz Bölge'sine yaklaşık ne kadar yağış düşmüştür?

S6b. En fazla ve en az yağış düşen bölgelerimiz hangileridir? Bunlar arasındaki yağış farkını tam olarak söyleyebilir miyiz?

S6c. Yağış miktarı birbirine en yakın olan iki bölge hangisidir?

K.4. Ağaç şeması yaparak verileri düzenler.
S5. Aşağıdaki bilgileri ağaç şemasıyla düzenleyiniz.

Canlılar beslenme şekillerine göre üçe ayrılırlar: etçiller, otçullar hem etçiller hem otçullar. Köpek, kurt, kartal ve timsah etçillere örnektir. Fil zürafa, inek ve koyun otçullara örnektir. İnsan, ayı, maymun ve kaplumbağa ise hem etçil hem otçullara örnek olarak verilebilir.

Tablo 1'de görüldüğü üzere sorulardan; S1'de öğrencilerden istatistiksel araştırma sorusu olup olmadığını bulmaları istenirken, S2 de ise verilenlere göre araştırma soruları oluşturmaları istenmektedir. Hazırlanan sorularda öğrencilerin; S3'te verilen çetele tablosunu sıklık grafiğine dönüştürmeleri ve verilen soruyu tabloya göre yorumlamaları istenirken; S4'te ilgili verilerle sütun grafiği oluşturmaları; S5'te verilen bilgilerle ağaç şeması oluşturmaları; S6a, S6b ve S6c de ise verilen sütun grafiği ile ilgili soruları cevaplamaları istenmiştir.

\section{Bulgular}

Öğrencilerin sorulara verdikleri doğru, kısmen doğru, yanlış ve boş cevaplar doğrultusunda hesaplanan frekans (f) ve yüzde değerleri (\%) Tablo 2'de sunulmuştur:

Tablo 2. Ortaokul Beşinci Sınıf Öğrencilerinin Sorulara İlişkin Cevapları

\begin{tabular}{|c|c|c|c|c|c|c|c|}
\hline \multirow{3}{*}{ Kazanımlar } & \multirow{3}{*}{ Sorular } & \multicolumn{6}{|c|}{ Cevaplar } \\
\hline & & \multicolumn{2}{|c|}{ Doğru (D) } & \multicolumn{2}{|c|}{ Yanlış (Y) } & \multicolumn{2}{|c|}{ Boş (B) } \\
\hline & & $\%$ & f & $\%$ & $f$ & $\%$ & f \\
\hline \multirow{2}{*}{ K1 } & S1 & 64,15 & 34 & 18,86 & 10 & 16,98 & 9 \\
\hline & S2 & 58,49 & 31 & 9,43 & 5 & 32 & 17 \\
\hline \multirow{2}{*}{ K2 } & S3a & 37,73 & 20 & 28,30 & 15 & 33,96 & 18 \\
\hline & S4 & 39,62 & 21 & 16,98 & 9 & 43,39 & 23 \\
\hline K3 & S3b & 62,26 & 33 & 13,20 & 7 & 24,52 & 13 \\
\hline
\end{tabular}




\begin{tabular}{cccccccc}
\hline & S6a & 56,6 & 30 & 15,1 & 8 & 28,3 & 15 \\
\cline { 2 - 7 } & S6b & 56 & 30 & 22,64 & 12 & 20,75 & 11 \\
\cline { 2 - 8 } & S6c & 52,8 & 28 & 24,52 & 13 & 22,64 & 12 \\
\hline K4 & S5 & 43,39 & 23 & 7,54 & 4 & 49 & 26 \\
\hline
\end{tabular}

Tablo 2'de görüldüğü üzere ilk soru istatiksel araştırma sorusunu bulmaya yönelik bir soru olan bu soruya, öğrencilerin büyük çoğunluğu doğru cevap vermiştir. İkinci soruda da öğrencilerin yarıdan fazlası istatiksel araştırma sorusunu oluşturabildikleri, ancak istatistiksel araştırma sorusu oluşturma nedenleri hakkında herhangi bir fikirlerinin bulunmadığ araştırma sorusu oluşturmada daha başarılı oldukları ortaya çıkmıştır. İki şıklı üçüncü sorunun ilk şıkında sıklık tablosunun altında yer alan nottaki açıklamaya dikkat ederek çizim yapan öğrencilerin yarıya yakını doğru yaparken, 18 'i ise bu sorunun altında verilen nottaki açıklamaya dikkat etmedikleri, dolayısıyla bu soruya yanlış cevap verdikleri görülmüştür. Aynı sorunun diğer şıkkında ise öğrencilerin yaklaşık yüzde altmışının, sıklık tablosunu yanlış oluşturmakla birlikte soruda yer alan verileri, doğru yorumladıkları tespit edilmiştir. Dördüncü soruda, öğrencilerden sütun grafiği oluşturmaları istenmiş, ancak öğrencilerin yaklaşık yarısının bu soruya cevap vermekten kaçınarak bu soruyu boş bıraktıkları görülmüştür. Beşinci soru da verileri ağaç şeması yaparak düzenleyebilen öğrencilerin sayısı katılımcı öğrencilerin sayısının yarısı bile değildir. Son olarak altıncı soru da verilen sütun grafiğinin özetlenmesi ve yorumlanmasına ilişkin üç şıklı bir sorudan oluşmaktadır. Bu soruda da öğrencilerin yarısından fazlasının sütun grafiğini yorumlayabildikleri görülürken belli bir çoğunluğunda bu soruya cevap vermediği ve soruyu boş bıraktığı ortaya çıkmıştır.

\section{Kazanım: Veri toplamayı Gerektiren Araştırma Soruları Oluşturur}

Hazırlanan sorulardan birinci ve ikinci soruda öğrencilerin veri toplamayı gerektiren araştırma ile ilgili bilgilerinin neler olduğu ortaya konulmak istenmiştir.

\subsection{S1 Sorusuna İlişkin Bulgular ve Yorumlar}

Burada öğrencilere; "Okulumuz 3. sinıf öğrencileri 23 Nisan Ulusal Egemenlik ve Çocuk Bayramı'nda hangi etkinliklerin yer almasını istemektedir?" ve "Beşinci sınıf öğrencisi Yusuf'un en çok sevdiği müzik türü hangisidir?” şeklinde sorular yöneltilmiştir. Yanlış cevaplar incelendiğinde, öğrencilerin 34 tanesinin istatistiksel araştırma sorusunun ne olduğunu bildikleri fakat genel olarak neden istatistiksel araştırma sorusu olduğu hakkında bir fikirlerinin bulunmadığı, 10 tanesinin soruyu yanlış anladıkları, 9 tanesinin ise istatistiksel araştırma sorusu hakkında bir bilgiye sahip olmadıkları görülmüştür. Öğrencilerin cevapları incelendiğinde neredeyse her iki öğrenciden birinin soruyu yanlış cevapladığ görülmektedir. Bazı öğrencilerin ise soruyla hiç ilgisi olmayan, sorudan bağımsız cevaplar verdiği görülmüştür. Buradaki soru "a” şıkkında bulunmasına karşılık bazı öğrencilerin soruyla hiçbir ilişkisi olmayan ve sorudan bağımsız şıklardaki sorulara yanıtlar verdikleri belirlenmiştir. Öğrencilerin bu soruya verdikleri ilgisiz ve yanlış cevaplardan bazıları aşağıda verilmiş̧ir:

“Pop müzik. (Ö1)”

"Tuttu firlattı kalbimi. (Ö4)"

"Her türlü müziği sever. Ama en çok rock-pop. (Ö7)”

"Yusuf? :). (Ö10)"

“a olur. (Ö25)” 
“yürüyüş. (Ö23)”

“dans. (Ö11)”

Öğrencilerin verdikleri yanlış cevaplar incelendiğinde, istatiksel araştırma sorusunun oluşturulma nedenlerini belirleyemedikleri tespit edilmiştir.

\subsection{S2 Sorusuna İlişkin Bulgular ve Yorumlar}

Burada da öğrencilere; “Bir hava yolu firmasına sahip olduğunuzu düşününüz. Sizin firmanızla seyahat etmeyi tercih eden yolcuların sayısı arttırmak istiyorsunuz. Bu amaçla müşterileriniz sizin hizmetinizle ilgili memnuniyet ve şikâyetlerini öğrenmeniz için yapacağınız araştırmada onlara ne tür sorular sorar, yolcuların görüşleri hakkında bilgi sahibi olursunuz?” şeklinde bir soru yöneltilmiştir.

Tablo 2 incelendiğinde öğrencilerin yarıdan fazlasının yukarıda ele alınan soruya doğru cevap verdiği, 5 öğrencinin yanlış cevap verdiği, 17 öğrencinin ise bu soruyu boş bıraktığı tespit edilmiştir. Bu durum öğrencilerin araştırma sorusu oluşturmada daha başarılı olduklarının bir göstergesi olabilir. Yani çalışma grubundaki ortaokul beşinci sınıf öğrencilerinin doğrudan bilgi istenilen soruları çözmede daha çok zorlandığı, kendi düşüncelerini ifade etmede böyle bir zorluk yaşamadıkları görülmüş̧ür. Ancak ne var ki bu soruya da birinci soruda olduğu gibi sorulan soru ile hiçbir ilişkisi olmayan çok farklı cevaplar verdikleri de elde edilen bulgular arasındadır. Öğrencilerin bu soruya verdikleri bazı cevaplardan alıntılar aşağıda verilmiştir:

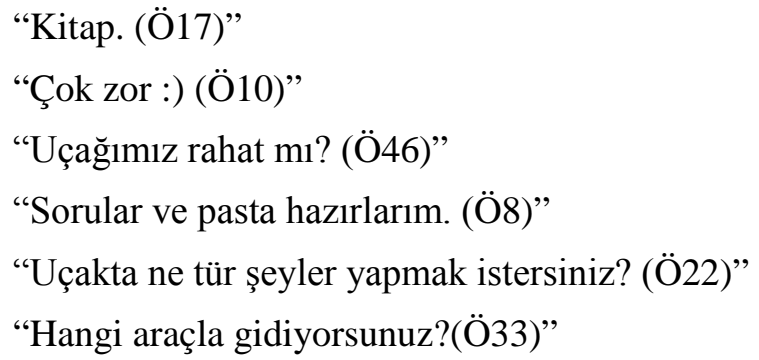

\section{Kazanım; Araştırma Sorularına İliş̧kin Verileri Toplar veya İlgili Verileri Seçer; Veriyi} Uygunluğuna Göre Sıklık Tablosu ve Sütun Grafiğiyle Gösterir

İkinci sorunun ilk şıkkı ve dördüncü sorunun amacı, bu bölümün kazanımında ulaşılmak istenen öğrencilerin; veri toplaması, veriyi sınıflandırması ve bunları sıklık tablosu ve sütun grafiğinde gösterebilmelerine ilişkin durumlarını ortaya çıkarmaktır.

\subsection{S3a Sorusuna İlişkin Bulgular ve Yorumlar}

$\mathrm{Bu}$ soruda öğrencilere; “Türkiye'nin katıldı̆̆ bazı olimpiyat oyunlarında kazandĭ̆ madalya sayıları aşağıdaki çetele tablosunda verilmişti, buna göre sıklık tablosunu çiziniz” şeklinde bir soru yöneltilmiştir.

Üçüncü soru incelendiğinde katılımcılardan 20 tanesinin a şıkkında verilen sıklık tablosunu doğru bir şekilde oluşturdukları, 15 katılımcının ise sıklık tablosu ile sütun grafiğini birbirine karıştırdıkları belirlenmiştir. Bunun yanı sıra öğrencilerin sorunun hemen altında verilen nottaki açıklama kısmına dikkat etmedikleri, 18 öğrencinin ise sıklık tablosu hakkında herhangi bir fikrinin olmadığı ve soruyu boş bıraktığı elde edilen sonuçlar arasındadır. Ayrıca bu soruda öğrencilerin bir kısmının sıklık tablosu ve sütun grafiğini ayırt etmede zorluk yaşadıkları ortaya çıkmıştır. 


\begin{tabular}{|l|c|c|c|}
\hline $\begin{array}{l}\text { Olimpiyat } \\
\text { oyunları }\end{array}$ & $\begin{array}{c}\text { Altın } \\
\text { Madalya }\end{array}$ & $\begin{array}{c}\text { Gümüs } \\
\text { Madalya }\end{array}$ & $\begin{array}{c}\text { Bronz } \\
\text { Madalya }\end{array}$ \\
\hline Sydney 2000 & 6 & 0 & 4 \\
\hline Atina 2004 & 6 & 8 & 6 \\
\hline Pekin 2008 & 2 & 8 & 6 \\
\hline Londra 2012 & 4 & 4 & 2 \\
\hline
\end{tabular}

Bu soruya verilmesi gereken cevabın yukarıdaki gibi olması beklenirken, 15 öğrencinin verilen çetele tablosunu sıklık tablosuna dönüştüremedikleri, üstelik sıklık tablosu yerine sütun grafiği kullanma yoluna gittikleri belirlenmiştir. Buna öğrencilerin tablo ile grafik kavramlarını zihinlerine yeterince yerleşmemiş olması neden olabilir. Aşağıda Ö57'nin verdiği cevap buna bir örnek teşkil etmektedir:

Ayrıca öğrencilerin bazılarının da bu soruda verilen çetele tablosunun hemen altında yer alan "Not: Her çizgi 2 madalyayı göstermektedir." açıklamasına dikkat etmedikleri dolayısıyla sıklık tablosunu oluştururken madalya sayılarını yanlış ifade ettikleri ortaya çıkmıştır. Aşağıda bir öğrencinin bu soruya ilişkin cevabı görülmektedir:

\subsection{S4 Sorusuna İlişkin Bulgular ve Yorumlar}

$\mathrm{Bu}$ soruda da öğrencilere; "Aynı mobil iletişim şirketi ve aynı tarifeye üye olan Hasan, Ahmet, Hülya, Murat, Yasemin'in cep telefonu faturast

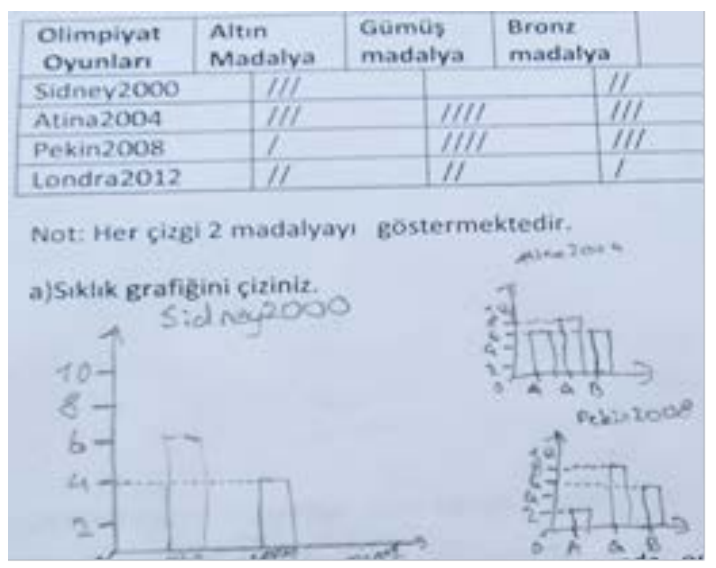

Fig. 1. Ö57'nin Sıklık Tablosu Oluşturmaya İlişkin Cevabı dökümlerine göre bir ayda gönderdikleri kısa mesaj saylları sirasıyla 110, 100, 85, 55, 145 'tir. Bu verilere iliş̧kin sütun grafiğini oluşturunuz?” şeklinde bir soru yöneltilmiştir.

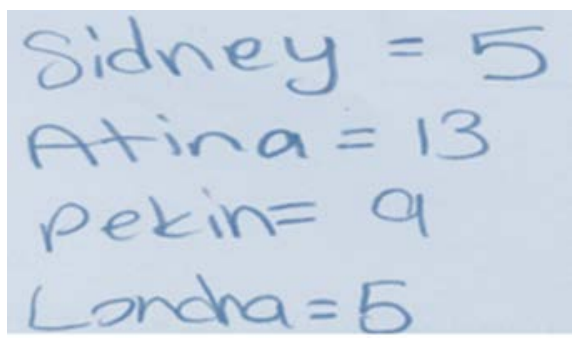

Fig. 2. Ö23'nin Sıklık Tablosu Oluşturmaya İlişkin Cevabı
Öğrenciler burada sütun grafiğini oluşturmada problem yaşamışlardır. Öğrencilerden 21 'inin soruyu anlayıp doğru cevapladıkları, 9 tanesinin yanlış çözdüğü, 23 öğrencinin ise soru hakkında hiçbir fikir ileri sürmeyerek soruyu boş bıraktığı ortaya çıkmıştır. Öğrencilerin büyük bir çoğunluğu verileri grafik olarak ifade etmede zorlanmışlardır. Katılımcıların pek çoğunun soruyu anlama, yorumlama ve grafiği oluşturmada problem yaşadıkları tespit edilmiştir. Öğrencilerin, özellikle bu türden sorularda görsel bir durum aradıkları ve bu görsele göre bir cevap oluşturmak istedikleri belirlenmiştir. Bazı öğrencilerin ise sütun grafiği ile sıklık tablosunu karıştırdıkları, bu konuda kararsız kaldıklarından ötürü sorunun cevabına, hem sıklık tablosunu hem de sütun grafiğini çizdikleri görülmüştür. Soruya verilen yanlış cevaplardan birkaç örnek aşağıda verilmiştir:

“Oluşturamıorum (Ö10)” 


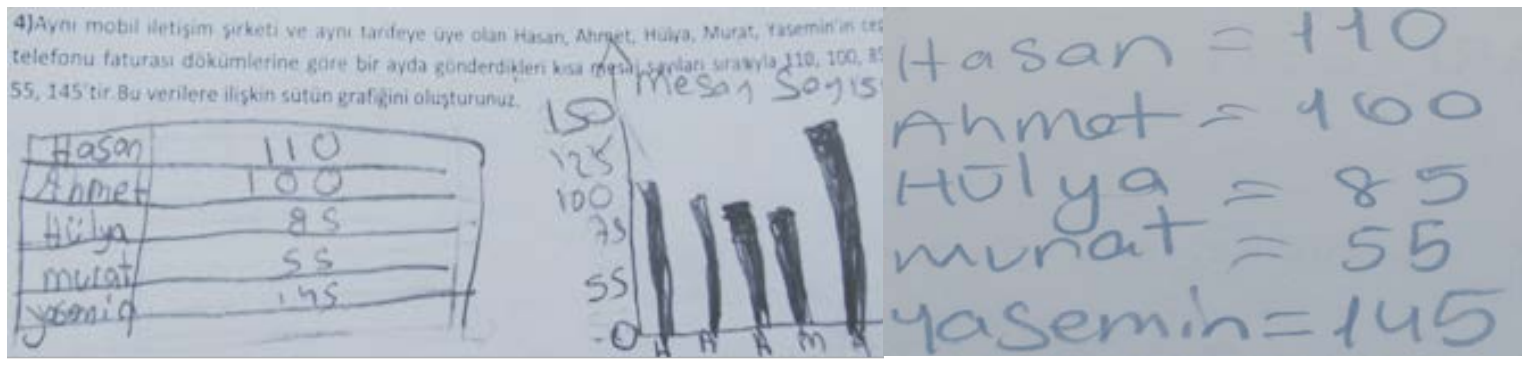

Fig. 3. Ö7'nin Sütun Grafiği Oluşturmaya İlişkin Cevabı

Fig. 4. Ö23'ün Sütun Grafiği Oluşturmaya İlişkin Cevabı

\section{Kazanım; Sıklık Tablosu, Sütun ve Ağaç Şemasını ile Gösterilmiş Veriyi Özetler ve Yorumlar}

Üçüncü sorunun b şıkkının ve altıncı sorunun a, b, c şıklarında, öğrencilerin verilen grafikleri yorumlama ve özetlemesine ilişkin bilgilerinin ortaya çıkartılması hedeflenmiştir.

\subsection{S3b Sorusuna İlişkin Bulgular ve Yorumlar}

Burada öğrencilere; “Türkiye'nin katıldı̆̆ bazı olimpiyat oyunlarında kazandı̆̆ı madalya saylları aşağıdaki çetele tablosunda verilmiştir. Buna göre; Türkiye belirtilen dört olimpiyat oyununda en fazla madalyayı hangi olimpiyat oyununda kazanmıştır?” şeklinde bir soru yöneltilmiştir.

Çetele tablosunda verilen verileri yorumlamalarının istendiği bu soruyu; 33 öğrencinin doğru cevap verdiği, 7'sinin soruyu tam anlayamadıkları ve bu nedenle sıklık tablosuna yanlış cevap verdikleri, 13 öğrencinin ise soruyu boş bıraktıkları belirlenmiştir. Yorumlamalar sonucunda doğru cevabın: “Atina 2004 Olimpiyat Oyunu” olması gerekirken öğrencilerin bir kısmının cevap olarak akıllarına gelen bazı olimpiyat oyunlarını örnek olarak vermeleri oldukça ilgi çekicidir. Üstelik bu soruya bazı öğrenciler sütun grafiği çizerek cevap vermeye çalışmışlardır. Dolayısıyla öğrencilerin yanlış oluşturdukları grafik verileri, yanlış yorumlamalarına neden olmuştur. Verilen yanlış cevaplardan bir tanesi aşağıdaki gibidir:

\subsection{S6a, S6b ve S6c Sorularına İlișkin Bulgular ve Yorumlar}

Burada öğrencilere; "Meteoroloji Genel Müdürlüğü tarafindan hazırlanan ve 2012 yllında bölgelerimize düşen yağış miktarını gösteren grafik aşăğda verilmiştir” şeklinde verilen ve üç şıktan oluşan bir soru yöneltilmiştir.

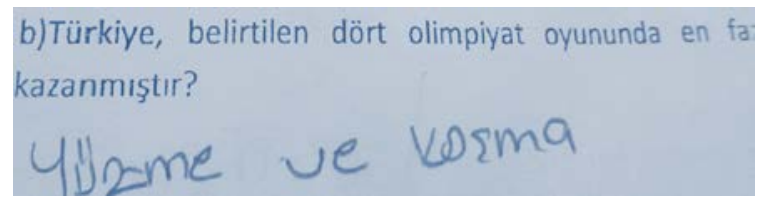

Fig. 5. Ö23'ün Sıklık Tablosu ile Gösterilmiș Veriyi Özetleme ve Yorumlamaya İlişkin Cevabı

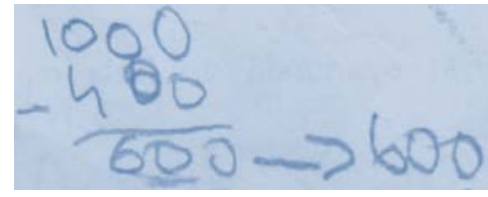

Fig. 6. Ö7'nin Sütun Grafiği ile Gösterilmiş Veriyi Özetleme ve Yorumlamaya İlişkin Cevabı

Bu sorunun ilk şıkkında; "Karadeniz Bölge’sine yaklaşık ne kadar yağış düşmüştür?” sorusuna verilen cevaplar incelendiğinde: öğrencilerin 30'u doğru, 8'inin "Yaklaşık” ifadesini anlayamadıkları, dolayısıyla grafikteki verileri yanlış yorumladıkları, 15'inin ise grafikteki verileri yorumlama konusunda herhangi bir fikre sahip olmadıkları ve soruyu boş bıraktıkları açığa çıkmıştır. Verilen yanlış cevaplardan bir tanesi aşağıdaki gibidir: 
$\mathrm{Bu}$ sorunun ikinci şıkkında; "En fazla ve en az yağış düşen bölgelerimiz hangileridir? Bunlar arasındaki yăğ farkını tam olarak söyleyebilir miyiz?” sorusuna verilen cevaplar incelendiğinde: 30 öğrencinin grafikteki verileri doğru yorumladığı ortaya çıkmıştır. Öğrencilerden 12 'sinin ise grafiği ve sayısal değerleri yanlış yorumladıkları, 11'nin ise grafikteki verileri yorumlamada sıkıntı yaşadıkları ve soruyu boş bıraktıkları tespit edilmiştir. Bu sorunun ikinci şıkkında, grafiği doğru olarak yorumlayamadıkları ve grafikte kesin değerlerle işlem yapmayı tercih ettikleri için; "Yağış farkını tam olarak söyleyebilir miyiz?" sorusuna "Söylenemez" cevabını veremedikleri belirlenmiştir. Soruya verilen yanlış cevaplardan birkaç tanesi aşağıda verilmişstir:

$$
\text { “800,5 (Ö31)” "805 (Ö33)” }
$$

Aynı sorunun üçüncü şıkkında "Yağıls miktarı birbirine en yakın olan iki bölge hangisidir?" sorusuna verilen cevaplar incelendiğinde: katılımcılardan 28'inin grafikteki verileri doğru yorumladıkları, 13'ünün grafikte verilen sayısal değerlere dikkat etmeyerek yanlış yorumladıkları, 12'sinin ise grafikteki verileri yorumlamada sorun yaşadıkları ve bu nedenle soruyu boş bıraktıkları görülmüştür. Bu sorunun üçüncü şıkkında öğrencilerin birbirine en yakın olan iki bölgeyi bulmakta sıkıntı yaşadıkları ulaşılan sonuçlar arasındadır. Grafikteki değerlere bakıldığında öğrenciler; "Güney Doğu Anadolu ve Doğu Anadolu Bölgesi” ile “Akdeniz ve Karadeniz Bölgesi”nin yağış miktarları birbirine yakın görünse de "Marmara ve Ege Bölgesi” doğru cevabını veremedikleri görülmüştür. Öğrencilerin burada sadece sütun grafiğinin görünümüne bakıp yağış miktarına dikkat etmeden yorum yapmaya çalıştıkları görülmektedir. Dolayısıyla da bu soruyu 13 öğrencinin “Akdeniz ve Karadeniz Bölgesi” şeklinde cevapladığı elde edilen sonuçlar arasındadır.

\section{Kazanım; Ağaç Şeması Yaparak Verileri Düzenler}

Öğrencilere sunulan başarı testinin beşinci sorunun amacı, öğrencilerin ağaç şeması çizebilmesine ilişkin bilgilerini ortaya çıkarmaktır.

\subsection{S5 Sorusuna İlişkin Bulgular ve Yorumlar}

Burada da öğrencilere; "Canlılar beslenme şekillerine göre üçe ayrllırlar: etçiller, otçullar hem etçiller hem otçullar. Köpek, kurt, kartal ve timsah etçillere örnektir. Fil zürafa, inek ve koyun otçullara örnektir. Insan, ayl, maymun ve kaplumbağa ise hem etçil hem otçullara örnek olarak verilebilir?” şeklinde soru yöneltilmiş ve bu bilgileri ağaç şemasında düzenlemeleri istenmiştir.

Tablo 2 incelendiğinde bu soruyu öğrencilerin 23'ünün doğru cevapladığı, 4'ünün ağaç şemasını oluşturamadıkları ve boş bıraktıkları görülmüştür. Öğrencilerin yarısından fazlasının ağaç şeması oluşturma konusunda zorluk yaşadıkları ulaşılan sonuçlar arasındadır. Verilerin ağaç şemasında doğru bir şekilde düzenlenmiş hali aşağıda verilmiştir:

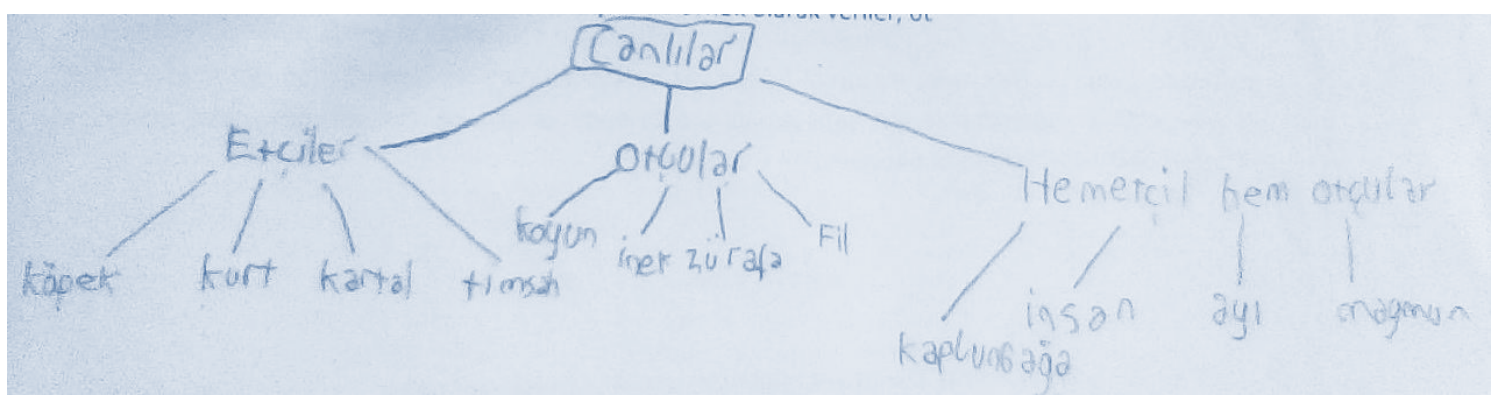

Fig. 7. Ö23’ün Ağaç Şeması Yaparak Veriyi Düzenlemeye İlişkin Doğru Cevabı 
Verilerin ağaç şemasında düzenlenmesine ilişkin yanlış cevaplardan birkaç tanesi aşağıda verilmiştir:

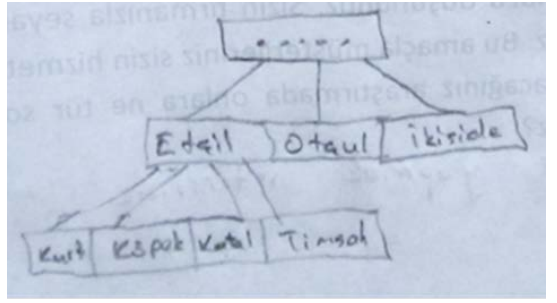

Fig. 8. Ö23’ün Ağaç Şeması Yaparak Veriyi Düzenlemeye İlişkin Yanlış Cevabı

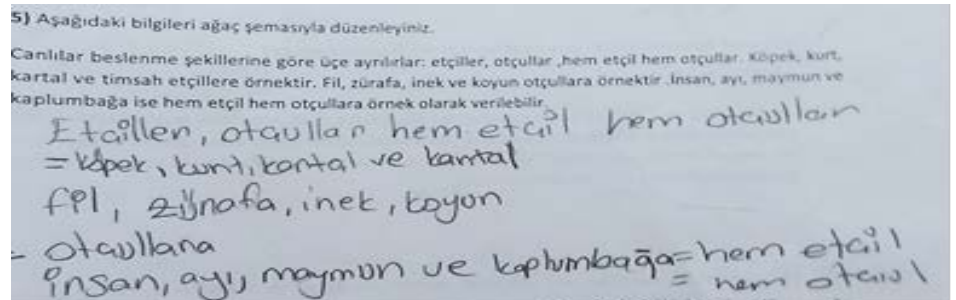

Fig. 9. Ö22’nin Ağaç Şeması Yaparak Veriyi Düzenlemeye İlişkin Yanlış Cevabı

Ayrıca bu soruda öğrenciler ağaç şeması oluşturmak yerine dördüncü sorudaki gibi sözel ifade kullanmışlardır. Bunlara örnek ifadeler; "Ben şema yapamam, çok zor (Ö10)", "Kitap (Ö17)" şeklindedir. Verilerden elde edilen sonuçlara dayalı olarak öğrencilerin, ağaç şeması oluşturmada zorluk yaşadıkları açık bir şekilde görülmektedir. Çalışma grubundaki öğrencilerin, "A ̆gaç şeması yaparak veriyi düzenler" kazanımına istenilen ölçüde ulaşamadıkları ortaya çıkmıştır.

\section{Tartışma, Sonuç ve Öneriler}

Öğrencilerin veri konusunda ulaşmaları hedeflenen konu ile ilgili kazanımları algılayışlarını tespit etmek amacıyla yürütülen çalışmanın sonuçlarına bakıldığında, çalışma kapsamında ele alınan bazı kazanımlara yeterince ulaşamadıkları açığa çıkmıştır. Elde edilen verilerin analizi sonucunda öğrencilerin; veri toplamayı gerektiren araştırma sorusu oluşturabildikleri ancak araştırma sorusu oluşturma nedenleri hakkında bir fikirlerinin bulunmadığı tespit edilmiştir. Bir diğer sonuç olarak, öğrencilerin neredeyse tamamının sıklık tablosu ve sütün grafiği oluşturmada, şema düzenlemede; sıklık tablosu, sütun ve ağaç şeması ile gösterilmiş veriyi özetleme ve yorumlamada zorluk yaşadıkları belirlenmiştir. Bunun yanı sıra öğrencilerin bir kısmı, sıklık tablosu ile sütün grafiğgini ayırt etmede de bir takım sorunlar yaşamışlardır.

$\mathrm{Bu}$ araştırmada öğrencilerin; birinci, ikinci ve altıncı sorulara, üçüncü sorunun ise ikinci şıkkına yüzde ellinin üzerinde doğru cevap verdikleri ulaşılan sonuçlar arasındadır. Öğrencilerin büyük bir çoğunluğunun istatistiksel araştırma sorusunun ne olduğunu bildikleri fakat genel olarak neden istatistiksel araştırma sorusu olduğu konusunda herhangi bir fikirlerinin olmadığ ortaya çıkmıştır. İkinci soruda öğrenciden istenilen yorum yapma noktasında genel olarak problem yaşamasalar da, üçüncü soruda da öğrencilerin büyük bir kısmının sıklık tablosunu sütun grafiği ile karıştırdıkları ve aynı sorunun hemen altında yer alan nottaki açıklamaya dikkat etmeyerek soruyu yanlış çözdükleri ortaya çıkmıştır. Buna öğrencilerin tablo ile grafik kavramlarını zihinlerine yeterince yerleşmemiş olması neden olabilir. Dördüncü soruda öğrencilerden sütun grafiği oluşturmaları istenmiş, ancak öğrencilerin yaklaşık yarısının bu soruya cevap vermekten kaçınarak soruyu boş bıraktıkları görülmüştür. $\mathrm{Bu}$ açıdan bakıldığında, çalışma grubundaki öğrencilerin ilköğretim birinci sınıftan, hatta okul öncesi dönemden itibaren her yıl veri konusunu çeşitli şekillerde görmüş olan beşinci sınıf öğrencisi olmaları düşündürücüdür.

Altıncı soruya; "Karadeniz Bölge'sine yaklaşık ne kadar yă̆ış düşmüştür? ” verilen cevaplar incelendiğinde öğrencilerin; 30'unun soruyu doğru cevaplandırdıkları, 8'inin "yaklaşık" ifadesini anlamayarak grafikteki verileri yanlış yorumladıkları, 15'inin ise grafikteki verileri yorumlama konusunda herhangi bir fikre sahip olmadıkları ve soruyu boş bıraktıkları açığa 
çıkmıştır. Verilen cevaplardan, öğrencilerin neredeyse hemen hepsinin soruların hemen ardında verilen, sorunun devamı niteliğindeki ikinci ifadeyi dikkate almadıkları, sadece sorunun ilk bölümüne odaklandıkları da ortaya çıkmıştır. Bunun nedeni, öğrencilerin sınav sürecinde yaşadıkları telaş, stres ve endişe gibi duyuşsal boyutlardan kaynaklı olabilir.

Araştırmanın sonuçlarından biri de öğrencilerin daha çok görsel şekilde ifade edilmiş soruları yorumlayabildikleri, sözel olarak verilen ve kendisinden bir tablo, grafik ya da şema oluşturması beklenen sorularda ise zorluk yaşadıkları şeklindedir. Bu sonuç, öğrencilerin verilen grafikler arasından uygun grafiği belirleme konusunda başarılı iken grafik oluşturmada yeterince başarılı olamadıkları sonucuyla uyuşmaktadır (Çelik \& Sağlam-Arslan 2012). Çalışmayla örtüşen benzer bir sonuç da Oruç ve Akgün'ün (2010) yedinci sınıf öğrencileri ile yaptıkları çalışmalarında, öğrencilerin yaklaşık \%50'si $(\% 43,1)$ grafikleri yorumlamada başarılı olduklarını tespit ettikleri şeklindedir.

Çalışma kapsamında kullanılan soruların tamamından elde edilen bulgular öğrencilerin, araştırma sorusu üretme, veri toplama, düzenleme ve gösterme, veri analizi ve yorumlamada, verilerin farklı temsil biçimlerinden grafik, tablo ve şema oluşturma ve bunları yorumlama konusunda güçlük yaşadıkları sonucunu ortaya koymaktadır. Araştırma sorusu üretme, veri toplama, düzenleme ve gösterme, veri analizi ve yorumlama, grafik, tablo ve şema gibi farklı gösterimlerin kavramların öğretiminde üstlendikleri role bakıldığında öğrencilerin sahip oldukları zorlukların büyük önem taşıdığı açıkça görülmektedir. Bu bağlamda matematikteki kavramlar, bireyin bilişinde yapılandırılan ilişkiler olduğundan, öğrencinin bilişinde matematiksel ilişkiler oluşmamışsa bu kavramlar kazanılamamakta ve bir sonraki öğrenme zorlaşmaktadır (Soylu \& Aydin 2006).

Güncellenen Ortaokul Matematik Öğretim Programı (MEB 2013) kavramsal öğrenmeyi desteklemek için öğrencilerin somut deneyimlerinden, sezgilerinden ve günlük yaşamdan getirdikleri informal bilgilerden faydalanılmasını öngörmektedir. Bu durum göz önüne alındığında, öğretmenlerden öğrencilerin eski bilgileri ile yeni bilgileri arasında ilişkilendirme yapabilecekleri ortamlar hazırlamaları beklenmektedir (Hacısalihoğlu Karadeniz, Bozkuş, Gündüz \& Baran 2015). Kavram bilgisi, kuralların, genellemelerin, bunlar arasındaki ilişkilerin ve işlemlerin altında yatan anlamları kapsamaktadır (Bekdemir, Okur \& Gelen 2010). Kavram bilgisinin tam olarak kazandırılabilmesi için konu ile ilgili tanımların, özelliklerin eksiksiz ve doğru olarak verilmesi gerektiği ifade edilmektedir (Küçük \& Demir 2009). Aksi durumda öğrencilerin kavram ve tanım üzerinde yapılan işlemleri ezberleme yoluna gittikleri dolayısıyla bu zorluğun üstesinden gelebilmek için süreçte kavramsal öğrenmeye daha fazla vurgu yapılması gerektiği ifade edilmektedir (Hacısalihoğlu Karadeniz et al. 2015). Bununla birlikte kavram geliştirmede rol oynayan bir faktör de teknolojiyi kullanarak kavramı öğretim içine yerleştirmektir (ÖzgünKoca, Meagher \& Edwards 2010). Sonuç olarak kavramsal bilgide bir durumun kavranması ön planda iken işlemsel bilgide bir kavram ya da işlemin nedeninin bilinmesinin önemi yoktur yalnızca nasıl kullanılacağını bilmek yeterlidir (Baki 1997).

Ortaokul beşinci sınıf öğrencilerinin veri işleme konusunda yaşadıkları zorlukların, öğrenim sürecinde sahip oldukları örnekler ile sınırlı olması bir neden olarak gösterilebilir. Bu durumun iyileştirilmesi amacıyla gösterim biçimleri ve aralarındaki geçişin, yürütülen derslerde detaylı bir şekilde ele alınması, uygulanması ve bu amaçla farklı yöntem ve tekniklerin geliştirilmesi önerilebilir. Bununla birlikte süreçte öğrencilere yakın çevrelerinden çeşitli örnekler sunulmalı, veri konusuyla ilgili materyaller tasarlanmalı ve öğrenme sürecinde öğrenciye bu materyallerle öğretim yapılmalı, farklı yöntem ve tekniklerden yararlanarak konuyu daha iyi kavramaları sağlamalıdır. Benzer biçimde bu kavramların öğretiminde somut nesnelerden, zenginleştirilmiş 
etkinliklerden ve farklı modellerden yararlanarak veri konusunun günlük hayatla ilişkilendirmesine özen gösterilmelidir. Ayrıca öğretim sürecinde matematiği kendi iç disiplinlerinden "Sayılar ve İşlemler", "Cebir", "Geometri ve Ölçme", diğer disiplinlerden Sosyal Bilgiler ve Fen ve Teknoloji derslerinde de veri konusuyla ilgili ilişkilendirmeler yapılarak öğrencilerin bu ilişkileri görmelerine ve yaşadıkları zorlukların giderilmesine yardımcı olunabilir. Son olarak öğrencilere veri işleme konusunda deneyim kazandırırken; araştırma sorusu üretme, veri toplama, düzenleme ve gösterme, veri analizi ve yorumlama etkinliklerine daha fazla yer verilmesi önerilebilir. 


\section{KAYNAKÇA}

Ateş S. (2001). The Effects of Computer Applications on Line-Graphing Skills of Tenth Grade Students Having Different Cognitive Developmental Levels. Yayımlanmamış Doktora Tezi Lexington: The Graduate School of Kentucky 2001.

Aydoğdu B. (2006). İlköğretim Fen ve Teknoloji Dersinde Bilimsel Süreç Becerilerin Etkileyen Değişkenlerin Belirlenmesi. Yayınlanmamış Yüksek Lisans Tezi. Dokuz Eylül Üniversitesi Eğitim Bilimleri Enstitüsü. İzmir 2006.

Bağcı-Kılıç G. (2003). "Üçüncü Uluslararası Matematik ve Fen Araştırması (TIMSS): Fen Öğretimi, Bilimsel Araştırma ve Bilimin Doğası”. İlköğretim-Online, 2/1 (2003) 42-51.

Bailer J., Ramig J. \& Ramsey J. (1995). Teaching Science Process Skills. California 1995.

Baki A. (1997). "Educating Mathematics Teachers". Medical Journal of Islamic Academy of Sciences 10/3 (1997) 93-102.

Bekdemir M., Okur M., \& Gelen S. (2010). "The effects of 2005 Elementary Mathematics Education Curriculum on the Elementary Seventh Grade Students' Conceptual and Procedural Knowledge and Skills”. Journal of Erzincan Faculty of Education 12/2 (2002) 131-147.

Bell A. \& Janvier C. (1981). “The Interpretation of Graphs Representing Situations”. For the Learning of Mathematics 2/1 (1981) 34-42.

Berg C. A. \& Philips D. G. (1994). "An Investigation of the Relationship Between Logical Thinking Structures and the Ability to Construct and Interpret Line Graphs". Journal of Research in Science Teaching 31/4 (1994) 323-344.

Brasell H. M. (1990). “Graphs, Graphing, and Graphers”. Ed. M.R. Rowe. What Research Says to the Science Teacher. (1990) 69-85. Washington.

Brasell H.M. \& Rowe M.B. (1993). "Graphing Skills Among High School Physics Students”. School Science and Mathematics 93 (1993) 62-70.

Çelik D. \& Sağlam-Arslan A. (2012). "The Analysis of Teacher Candidates' Translating Skills in Multiple Representations”. Elementary Education Online 11/1 (2012) 239-250.

Clement, J. (1989). "The Concept of Varietion and Misconceptions in Cartesian Graphing”. Focus on Learning Problems in Mathematics 11/2 (1989) 77-87.

Çepni S., Ayas, A., Johnson D. \& Turgut M. F. (1997). Fizik Öğretimi. Ankara 1997.

Çepni S. (2014). Araştırma ve Proje Çalışmalarına Giriş (7. Baskı). Trabzon 2014.

Demirci N. \& Uyanık, F. (2009). "Onuncu Sınıf Öğrencilerinin Grafik Anlama ve Yorumlamaları İle Kinematik Başarıları Arasındaki İlişki”. Necatibey Eğitim Fakültesi Elektronik Fen ve Matematik Eğitimi Dergisi (EFMED) 3/2 (2009) 22-51.

Deveci Ö. (2010). İlköğretim Altıncı Sınıf Fen ve Teknoloji Dersi Kuvvet ve Hareket Ünitesinde FenMatematik Entegrasyonunun Akademik Başarı ve Kalıcılık Üzerine Etkisi. Yayımlanmamış Yüksek Lisans Tezi, Çukurova Üniversitesi, Adana 2010.

Güleç S. \& Alkış S.(2003). "Illköğretim Birinci Kademe Öğrencilerinin Derslerdeki Başarı Düzeylerinin Birbiriyle İlişkisi”. İlköğretim-Online, 2/2 (2003) 19-27.

Hacısalihoğlu Karadeniz M., Aydın Güç F. \& Tülek G. (2014). "Sekizinci Sınıf Öğrencilerinin Süslemelerdeki Başarılarının Düzenli-Yarı Düzenli ve Düzensiz Süslemeler Bağlamında İncelenmesi”. 1. Eurasian Educational Research Congress, İstanbul 2004.

Hacısalihoğlu Karadeniz M., Bozkuş F., Gündüz N., \& Baran T. (2015). "Difficulties of Prospective Elementary Mathematics Teachers' Regarding to Reflection Symmetry". Turkish Journal of Computer and Mathematics Education, 6/1 (2015) 117-138.

Hughes C. \& Wade W. (1993). Inspirations for Investigations in Science. Warwickshire 1993.

Kılıç Ç. \& İncikabı L. (2013). “İlköğretim Öğrencilerinin Geometrik Cisimlerle İlgili Kavram Bilgilerinin Analizi. An Analysis of Primary School Students' Conceptual Knowledge of Geometric Solids”. Kuramsal Eğitimbilim Dergisi (2013) 343-358.

Küçük A. \& Demir B. (2009). "İlköğretim 6-9. Sınıflarda Matematik Öğretiminde Karşılaşılan Bazı Kavram Yanılgıları Üzerine Bir Çalışma”. Dicle Üniversitesi Ziya Gökalp Eğitim Fakültesi Dergisi 
13 (2009) 97-112.

Leinhardt G., Zaslavsky O. \& Stein M. K. (1990). “Functions, Graphs and Graphing: Tasks, Learning and Teaching”. Review of Educational Research 60/1 (1990) 1-64.

Martin D. J. (2002). Elementary Science Methods a Constructivist Approach. Newyork 2002.

Milli Eğitim Bakanlığı (MEB). (2009a). İlköğretim Matematik Dersi (1-5. Sinıflar) Öğretim Programı. Talim Terbiye Kurulu Başkanlığ , Ankara 2009.

Milli Eğitim Bakanlığı (MEB). (2009b). İlköğretim Matematik Dersi (6-8. Sınıflar) Öğretim Programı. Talim Terbiye Kurulu Başkanlığ 1 , Ankara 2009.

MEB, (2013). Ortaokul Matematik Dersi (5, 6, 7 ve 8. Sinıflar) Öğretim Programı. MEB Talim ve Terbiye Kurulu Başkanlığ1, Ankara 2013.

National Council of Teachers of Mathematics. NCTM. (2000). Principles and Standards for School Mathematics. Virginia 2000.

Oruç Ş. \& Akgün, İ. H. (2010). "İlköğretim Sosyal Bilgiler 7. Sınıf Öğrencilerinin Grafik Okuma Becerisini Kazanma Düzeyleri”. Uluslararası Avrasya Sosyal Bilimler Dergisi, $1 / 1$ (2010) 51-58.

Özgün-Koca S. A. (2001). The Graphing Skills of Students in Mathematics and Science Education. (2009, 25-July). Kaynak: http://www.gpoaccess.gov/eric/200211/ed464804.pdf.

Özgün-Koca S. A. (2008). Öğrencilerin Grafik Okuma, Yorumlama ve Oluşturma Hakkındaki Kavram Yanılgıları. Ed. M. F. Özmantar, E. Bingölbali \& H. Akkoç. Matematiksel Kavram Yanılgıları ve Çözüm Önerileri (2008) 61-89. Ankara.

Özgün-Koca S. A., Meagher M. \& Edwards M. T. (2010). "Preservice Teachers' Emerging TPACK in a Technology-Rich Methods Class”. The Mathematics Educator 19/2 (2015) 10-20.

Padilla J. M., McKenzie L. D. \& Shaw L. E. (1986). “An Examination of Line Graphing Ability of Students in Grades Seven Through Twelve”. School Science and Mathematics 86 (1986) 20-16.

Piez C. M. \& Voxman M. H. (1997). "Multiple Representations-Using Different Perspectives to Form a Clearer Picture”. Mathematics Teachers 90/2 (1997) 164-166.

Soylu Y. \& Aydin S. (2006). “A Study on Importance of the Conceptual and Operational Knowledge are Balanced in Mathematics Lessons”. Journal of Erzincan Faculty of Education 8/2 (2006) 83-95.

Schultz J. E. \& Waters M. (2000). “Why Representations?”. Mathematics Teachers 93/6 (2000) 448-453.

Taşar M. F., Temiz B. K. \& Tan M. (2002). İlköğretim Fen Öğretim Programında Hedeflenen Öğrenci Kazanımlarının Bilimsel Süreç Becerilerine Göre Sınıflandırılması. V. Ulusal Fen Bilimleri ve Matematik Eğitimi Kongresi 16-18 Eylül 2002. Ankara.

Temiz B. K. ve Tan M. (2009). “Grafik Çizme Becerilerinin Kontrol Listesi İle Ölçülmesi”. Selçuk Üniversitesi Ahmet Keleşoğlu Eğitim Fakültesi Dergisi 27 (2009) 71-83. 